\title{
TIME-VARYING VOLATILITY MODELLING OF BALTIC STOCK MARKETS
}

\author{
Bora Aktan ${ }^{1}$, Renata Korsakiené ${ }^{2}$, Rasa Smaliukiené $\dot{3}^{3}$ \\ ${ }^{1}$ Yasar University, Faculty of Economics and Business, Department of Finance, \\ Selcuk Yasar Campus, 35100 Bornova, Izmir, Turkey \\ 2, 3 Vilnius Gediminas Technical University, Sauletekio al 11, 10223 Vilnius, Lithuania \\ E-mail: ${ }^{1}$ bora.aktan@yasar.edu.tr (corresponding author); ${ }^{2}$ renatakorsa@takas.lt; \\ 3 rasa.smaliukiene@vgtu.lt
}

Received 10 October 2009; accepted 27 May 2010

\begin{abstract}
As time-varying volatility has found applications in roughly all time series modelling in economics, it largely draws attention in the areas of financial markets. This study also examines the characteristics of conditional volatility in the Baltic Stock Markets (Estonia, Latvia and Lithuania) by using a broad range of GARCH volatility models. Correctly forecasting the volatility leads to better understanding and managing financial market risk. Daily returns from four Baltic stock indexes are used; Estonia (TALSE index), Latvia (RIGSE index), Lithuania (VILSE index) and synthetic BALTIC benchmark index. We test a large family of GARCH models, including; the basic GARCH model, GARCH-in-mean model, asymmetric exponential GARCH and GJR GARCH, power GARCH and component GARCH model. We find strong evidence that daily returns from Baltic Stock Markets can be successfully modelled by GARCH-type models. For all Baltic markets, we conclude that increased risk will not necessarily lead to a rise in the returns. All of the analysed indexes exhibit complex time series characteristics involving asymmetry, long tails and complex autoregression in the returns. Results from this study are firmly recommended to financial officers and international investors.
\end{abstract}

Keywords: Baltic stock markets, conditional volatility, GARCH models, financial risk, returns.

Reference to this paper should be made as follows: Aktan, B.; Korsakienè, R.; Smaliukienè, R. 2010. Time-varying volatility modelling of Baltic stock markets, Journal of Business Economics and Management 11(3): 511-532.

\section{Introduction}

Volatility is a fundamental characteristic of financial markets whose measuring and forecasting has always been important, but even more so in the current crisis. Volatility is a measure of the intensity of random or unpredictable changes in asset returns. Constant volatility models such as ARMA only refer to the unconditional volatility of a returns process. Processes that model unconditional volatility presume a constant variance of the time series throughout the whole data generation process. Such volatility can be defined in terms of the variance parameter of the unconditional distribution of a stationary returns process. In fact, unconditional volatility is only defined if it is assumed that a stationary 
stochastic process generates the asset return series, but this assumption seems far more reasonable than many other assumptions that are commonly made in financial models. Time-varying volatility models describe a process for the conditional volatility. A conditional distribution, in this context, is a distribution that governs a return at a particular instant in time. In more general terms, a conditional distribution is any distribution that is conditioned on a set of known values for some of the variables, that is, on information set (Alexander 2001). In time series models the information set at time $t, I_{t}$ is often taken as all the past values that were realized in the process. Conditional volatility at time $t$ is the square root of the variance of the conditional distribution at time $t$. The conditional mean at time $t$ is denoted $E_{t}\left(\frac{r_{t}}{r_{t-i}}\right)$ or $\mu_{t}$ and the conditional variance at time $t$ is denoted $V_{t}\left(\frac{r_{t}}{r_{t-i}}\right)$ or $\sigma_{t^{2}}$ (Engle 1982). An estimation procedure for the time-varying parameters of the conditional distributions is based on a model where anything that has happened in the past is not considered to be an observation on the current random variable. Its value is known, and so past observations become part of the information set. That is, the actual rather than the expected values of anything that happened in the past will be used to estimate the current value of a time-varying volatility parameter. Put another way, the current (and future) conditional distributions of the random variable will be "conditioned" on the current information set.

The conditional volatility has no place in the standard framework for linear regression, because standard linear regression assumes that returns are homoskedastic - that is, their conditional variance is the same throughout the process. The term conditional heteroskedasticity means that the conditional variance changes over time. The episodes of high and low volatility are often called volatility clusters.

This phenomenon shows the possibility of forecasting volatility. High volatility periods tend to persist before falling to lower levels. Financial returns also tend to be leptokurtic, which makes them even harder to model since they are not even asymptotically normal. These characteristics of financial time series were noted in the early works of Mandelbrot (1963), Fama (1965), Clark (1973) and Blattberg and Gonedes (1974). This early research led to modelling financial returns as IID draws from thick tailed distributions such as Student's t and a family of distributions known as Stable Paretian distributions.

The increased interest in risk management in financial theory has necessitated the development of new econometric time series models that take into account time variation of variances and covariances. Volatility can be thought of as a random variable that follows a stochastic process. Discovering the underlying stochastic process is the task of every volatility model. Financial data shows that volatility clusters vary significantly in their persistence i.e. life span. Volatility clusters can be very short-lived, lasting only hours, or they may last for decades. These long-term volatilities are usually driven by certain economic processes or/and institutional changes. The primary source of changes in market prices is the arrival of news about the asset's fundamental value. If the news arrives in 
rapid succession, the returns exhibit a volatility cluster (Engle and Mezrich 1995).

The moving average model of volatility assumes that asset returns are independent and identically distributed (IID). There is no time-varying volatility assumption in any of the weighted moving average methods, be it a simple moving average or an exponential moving average. Moving average models only provide an estimate of the unconditional volatility, assumed to be a constant, and the current estimate is taken as the forecast. The volatility estimates do change over time, but this can only be attributed to noise or sampling errors in a moving average model (Alexander 2000).

In a GARCH model, returns are assumed to be generated by a stochastic process with time-varying volatility. Instead of modelling the data after they have been collapsed into a single unconditional distribution, a GARCH model introduces more detailed assumptions about the conditional distributions of returns. These conditional distributions change over time in an autocorrelated way, in fact the conditional variance, is in it self an autoregressive process. GARCH volatility forecasts are very flexible and can be adapted to any time period. The forward volatilities that are generated by GARCH models can have many applications. Valuing path-dependent options or volatility options, measuring risk capital requirements, calibration of binomial trees - all of these require forecasts of forward volatilities that have a mean-reverting property. Perhaps the most important of all the advantages of GARCH models is that they are based on a statistical theory that is justified by empirical evidence. Unlike constant volatility models, there is no need to impose unrealistic assumptions to force it into a framework that is inconsistent with its basic assumptions. This coherency has led to many applications of GARCH models to measuring financial risks and pricing and hedging of options.

Several studies investigate the performance of GARCH models on explaining volatility of some mature and emerging stock markets (e.g. Akgiray 1989; Sentana and Wadhwani 1992; Kim and Kon 1994; Kearney and Daly 1998; Tay and Zhu 2000; Teresiene 2009). In the study of Gurgul et al. (2006), they used GARCH models to illustrate that for the revelation of stock-market reactions to firm-specific news, trading volume contains precious information in excess of that manifested in stock prices. In addition to the studies conducted in mature market, Yalcin and Yucel (2006) analyzed 20 emerging markets for examining the Day-of-the-Week Effect in stock return through EGARCH-M model. Pošta (2008), with the use of an E-GARCH model of the volatility, shows how quickly the Prague Stock Exchange, represented by its PX index and PX-GLOBAL index, has gradually moved toward the condition of weak efficiency. Aslanidis et al. (2009) with the use of smooth transition conditional correlation (STCC) GARCH specification demonstrate that an investor will gain little from portfolio diversification across US and UK markets. Christiansen (2010) with the use of GARCH based family models decompose European bonds and stock volatility and found significant volatility-spillover effects. Mcmillan and Speight (2006) with the estimation of a FIGARCH model supports the contention that volatility dynamics result from multiple sources for high-frequency S\&P500 index and DM/\$ exchange rate.

In this paper we analyse characteristics of three national Baltic stock indexes; Estonia (TALSE index), Latvia (RIGSE index), Lithuania (VILSE index), and BALTIC bench- 
mark index ${ }^{1}$. Over a period of seven years, we test a large family of GARCH models, including; the basic GARCH model, GARCH-in-mean model, asymmetric exponential GARCH and GJR GARCH, power GARCH and component GARCH model. Asymmetric GARCH models have the additional advantage of explaining the potentially asymmetric nature of the response to past positive and negative shocks.

The paper has two goals; explain volatility modelling using recent daily data from Baltic stock markets, and evaluate the performance of GARCH-type models in explaining market risk in these markets prior to and during the current global financial crisis. The motivation for our paper is to add new evidence from three Baltic stock markets to the modelling of financial time series by explaining volatility clustering in these markets. It is important to both practitioners and academic to understand the evolution of prices in the emerging stock markets over time, as well as understanding the process of reaching financing decisions through volatility modelling.

The paper is organised as follows: Section 2 presents the characteristics of the used Baltic markets data set. Section 3 explains the employed GARCH methodology, while Section 4 presents the main empirical results. Section 5 concludes the paper and summarises the main findings.

\section{Data}

The data used in the analysis of volatility are the daily observations of the Baltic states (Estonia, Latvia and Lithuania) stock market indexes. The returns are collected for Bloomberg website in the period 01.02.2002-03.01.2009, which includes the current financial crisis in the global and regional markets. The data series range from 1795 daily observations for BALTIC benchmark index to 2079 daily observations for TALSE index.

Table 1 gives the descriptive statistics for daily stock market returns. All of the analyzed indexes show a slightly positive mean, which is not significantly different from zero, a finding that can be expected in the midst of the global crisis in emerging stock markets that were performing exceptionally strong prior to the crisis. Distribution of returns is not symmetrical and shows significant negative asymmetry (especially the combined BALTIC benchmark index). High excess kurtosis indicates the presence of extreme events that are highly unlikely to occur under the normality assumption. Consequently, all of the normality tests show that there is virtually no probability that the data generating processes behind these indexes are normally distributed.

In terms of stationarity, the results from the Augmented Dickey Fuller (ADF) and Phillips-Perron tests indicate that both series are I(1), and therefore, time-series models can be used to examine the behaviour of volatility over time. The daily index values and returns for each index are presented in Figures 1-4.

\footnotetext{
${ }^{1}$ For a broad discussion on Baltic States see Adekola et al. (2008); Tvaronaviciene et al. (2009); Melnikas (2008) and Plinkus (2010).
} 
Table 1. Descriptive Statistics for TALSE, VILSE, RIGSE and BALTIC Benchmark Index, Period 01.02.2002-03.01.2009

\begin{tabular}{lllll}
\hline Main Statistics & TALSE & VILSE & RIGSE & BALTIC \\
\hline Descriptive Statistics & & & & \\
Mean & 0.0003 & 0.0004 & 0.0001 & 0.0003 \\
Median & 0.0000 & 0.0000 & 0.0000 & 0.0008 \\
Minimum & -0.0705 & -0.0911 & -0.0786 & -0.0882 \\
Maximum & 0.0718 & 0.1100 & 0.0916 & 0.0794 \\
St. Dev. & 0.0100 & 0.0105 & 0.0110 & 0.0102 \\
Skewness & -0.7412 & -0.6749 & -0.4512 & -1.1451 \\
Kurtosis & 12.01 & 20.29 & 13.37 & 15.43 \\
\hline Normality Tests & & & & \\
Lilliefors & 7216.71 & 25667.56 & 9336.32 & 11948.16 \\
(p value) & 0.00 & 0.00 & 0.00 & 0.00 \\
Shapiro Wilk/Francia & 0.137 & 0.126 & 0.126 & 0.130 \\
(p value) & 0.00 & 0.00 & 0.00 & 0.00 \\
Jarque-Bera & 0.863 & 0.830 & 0.846 & 0.841 \\
(p value) & 0.00 & 0.00 & 0.00 & 0.00 \\
\hline Unit Root Tests & -27.211 & -27.729 & -30.401 & -25.393 \\
ADF (AR + drift) & -36.831 & -38.059 & -44.376 & -34.236 \\
P-P (AR + drift) & & & & \\
\hline
\end{tabular}

Source: Authors' calculations

\section{Methodology}

The fundamental idea in GARCH is to add a second equation to the standard regression model: the conditional variance equation (Enders 2004: 112). This equation describes the evolution of the conditional variance of the unexpected return process, $V_{t}\left(\varepsilon_{t}\right)=\sigma_{t}^{2}$ The dependent variable, the input to the GARCH volatility model, is always a return series, and accordingly a GARCH model consists of two equations. The first equation is the conditional mean equation. This can be anything, but since the focus of GARCH is on the conditional variance equation it is usual to have a very simple conditional mean equation. Many of the GARCH models used in practice take the simplest possible conditional mean equation $r_{t}=c+\varepsilon_{t}$, where $\mathrm{c}$ is a constant. In this case the unexpected return $\varepsilon_{t}$ is jus-t the mean deviation return, because the constant will be the average of returns over the data period. In some circumstances it is better to use a time-varying conditional mean, but on the other hand, using to many parameters in the conditional mean equation might lead to convergence problems. 

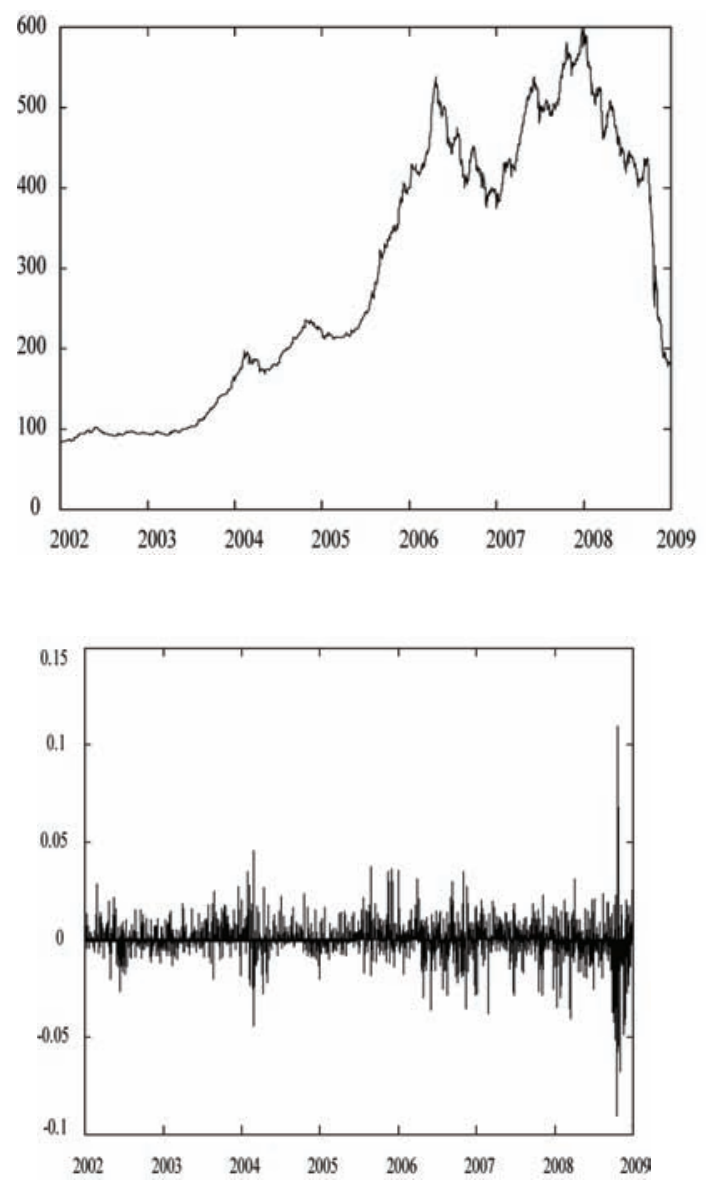

Fig. 1. VILSE Index Values and Return, Period 01.02.2002-03.01.2009

If there is significant autocorrelation in returns, autoregressive moving average conditional mean should be used to model the returns. The second equation in a GARCH model is the conditional variance equation. Different GARCH models arise because the conditional variance equations are specified in different forms. There is a fundamental distinction between the symmetric GARCH models that are used to model ordinary volatility clustering and the asymmetric GARCH models that are designed to capture leverage effects. In symmetric GARCH the conditional mean and conditional variance equations can be estimated separately. This kind of estimation is not possible for asymmetric GARCH models making their estimation more complex (Alexander 2001: 70). Underlying every GARCH model there is also an unconditional returns distribution. The unconditional distribution of a GARCH process will be stationary under certain conditions imposed on the GARCH parameters and if necessary these conditions can be imposed on the estimation. 

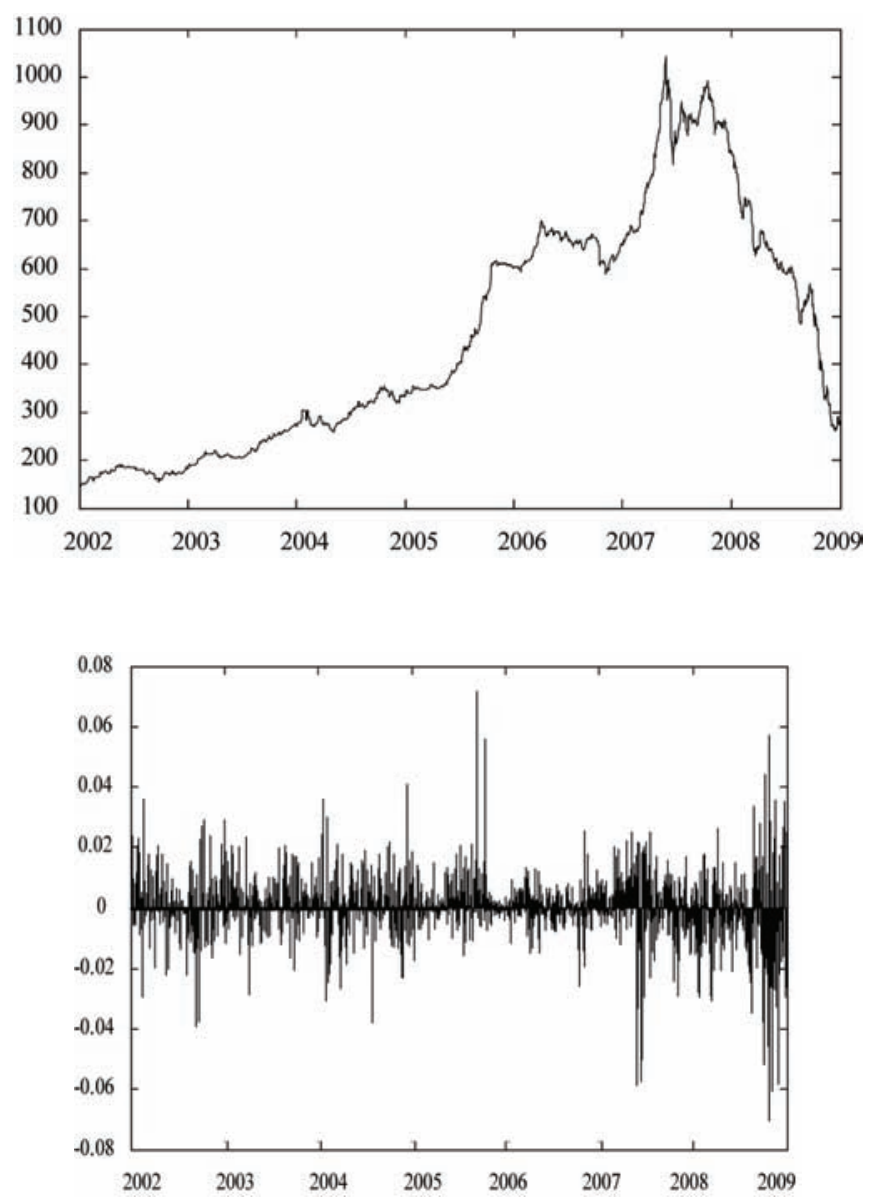

Fig. 2. TALSE Index Values and Return, Period 01.02.2002-03.01.2009

GARCH model extends the ARCH model by allowing for both the longer memory and a more flexible lag structure. In a GARCH model $\varepsilon_{t}$ denotes a real-valued discrete-time stochastic process whose conditional distribution is assumed to be normal (other probability distributions could also be applied such as Student's t) and $\psi_{\mathrm{t}}$ the information set ( $\sigma-$ field) of all information up till time $t$. Equations 1-3 represent next period's variance, forecasted by the GARCH $(p, q)$ process (Bollerslev 1986: 309). Following:

$$
\begin{gathered}
\frac{\varepsilon_{t}}{\psi_{t-1}} \approx N\left(0, \sigma t^{2}\right), \\
\sigma_{t^{2}}=a_{0}+\sum_{i=1} a_{i} \varepsilon^{2}{ }_{t-i}+\sum_{i=1} \beta_{i} \sigma_{t-i}^{2},
\end{gathered}
$$



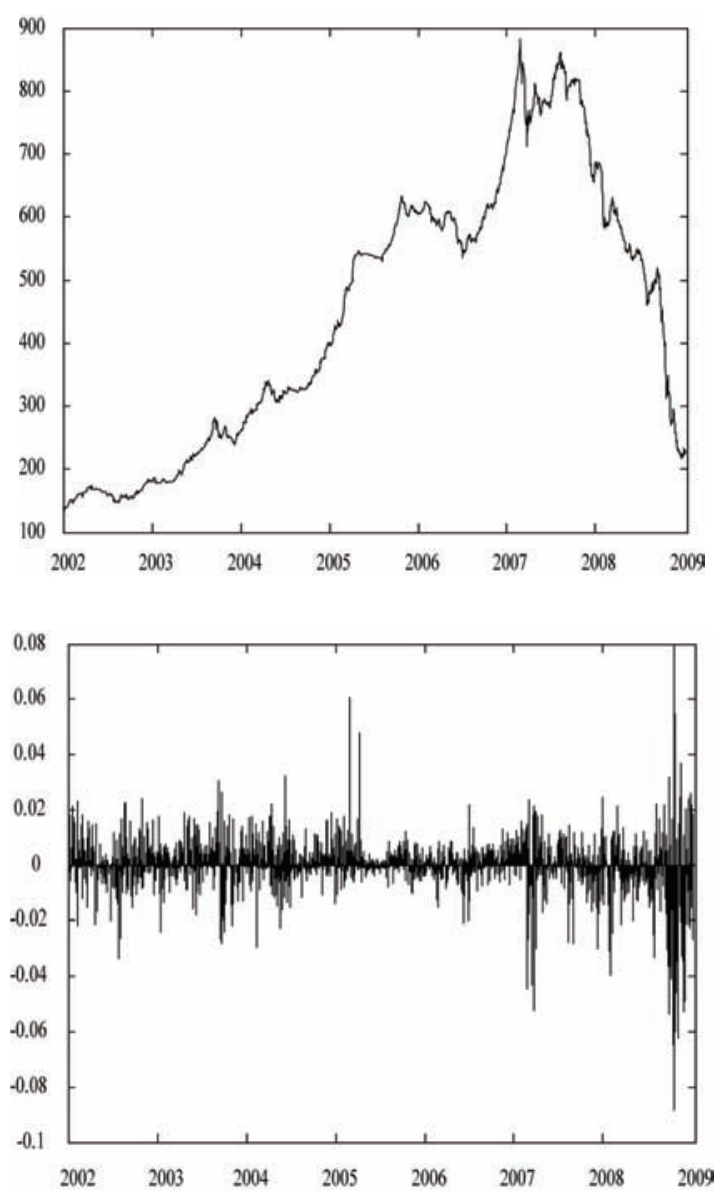

Fig. 4. BALTIC Benchmark Index Values and Return, Period 01.02.2002-03.01.2009

$$
\begin{gathered}
\sigma t^{2}=a_{0}+A(L) \varepsilon_{t}^{2}+B(L) \sigma_{t}^{2}, \\
p \geq 0, q>0, \\
a_{0}>0, a_{i} \geq 0, i=1, \ldots, q \\
\beta_{i} \geq 0, i=1, \ldots, p
\end{gathered}
$$

$a, \beta-$ GARCH parameters,

$\sigma_{t}^{2}$ - variance at time $(t)$,

$\boldsymbol{\varepsilon}_{t}-$ residual at time $(t)$, 

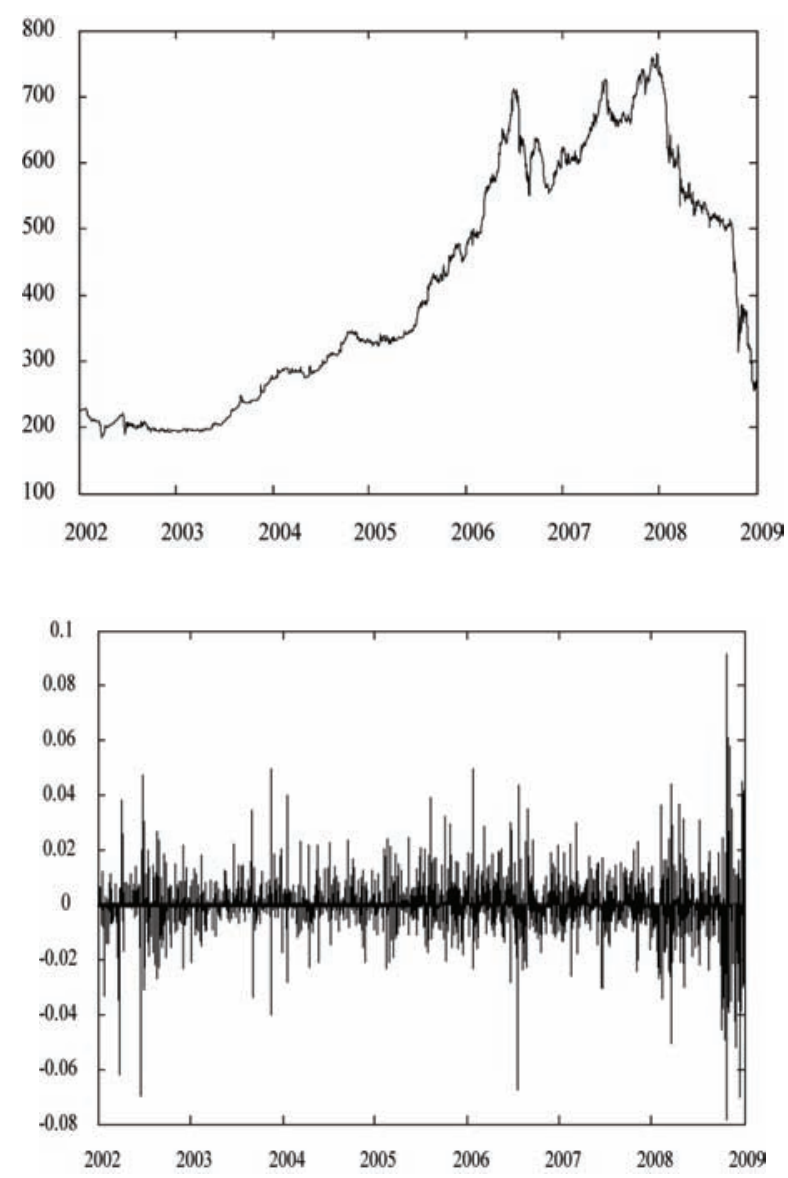

Fig. 3. RIGSE Index Values and Return, Period 01.02.2002-03.01.2009

when $p=0$ the process is reduced to the $\operatorname{ARCH}(q)$ process, and when $p=q=0$ the process becomes a white noise series $(\varepsilon)$. In the $\mathrm{ARCH}(\mathrm{q})$ process the conditional variance is specified as a linear function of past sample variances, whereas the $\operatorname{GARCH}(p$, q) process uses also lagged conditional variances.

The size of the parameters $\alpha$ and $\beta$ determines the short-run dynamics of the resulting volatility time series. Large GARCH lag coefficients $\beta$ ndicate that shocks to conditional variance take a long time to die out, so volatility is persistent. Large GARCH error coefficients $\alpha$ mean that volatility reacts intensely to market movements, and so if alpha is relatively high and beta is relatively low, volatilities tend to be spikier. In financial markets it is common to estimate lag coefficients based on daily observations in excess of 0.8 and error coefficients of no more than 0.2 (Alexander 2001: 73).

Presuming that the process starts indefinitely far in the past with $2 \mathrm{~m}$ finite initial mo- 
ments and structure of the GARCH process, $\alpha_{1}+\beta_{1}<1$ suffices for wide-sense stationarity. Equations 4-5 represent a necessary and sufficient condition for existence of the 2mth moment in a GARCH(1,1) process (Bollerslev 1986: 311). Following:

$$
\mu\left(\alpha_{1}, \beta_{1}, m\right)=\sum_{j=0}\left({ }_{j}^{m}\right) a_{j} a_{1}^{j} \beta_{1}^{m-j}<1
$$

where

$$
\alpha_{0}=1, a_{j}=\prod_{i=1}^{j}(2 j-1), j=1, \ldots
$$

The 2mth moment can be expressed by the recursive Equation 6. Following:

$$
E\left(\varepsilon_{t}^{2 m}\right)=\alpha_{m}\left[\sum_{n=0}^{m-1}\left\{a_{n}^{-1} E\left(\varepsilon_{t}^{2 n}\right) a_{0}^{m-n}\left(\begin{array}{c}
m \\
m-n
\end{array}\right) \mu\left(a_{1},\right\} \beta_{1}, n\right)\right] \times\left[1-\mu\left(a_{1}, \beta_{1}, m\right)\right]^{-1} .
$$

As $\varepsilon_{\mathrm{t}}$ is conditionally normal, by symmetry it follows that if the first $2 \mathrm{~m}^{\text {th }}$ moments exist, $E\left(\varepsilon_{t}^{2 m-1}\right)=0$. This directly relates to the fact that skewness coefficient (third moment) must be equal to zero. For $\beta_{1}=0$, Equation 4 reduces to the well-known condition for the $\mathrm{ARCH}(1)$ process, $a_{m} a_{1}^{m}<1$ (Engle 1982: 992). If $a_{1}>1\left(a_{m}\right)^{-\frac{1}{m}}$ in the $\operatorname{ARCH}(1)$ process, the $2 \mathrm{~m}^{\text {th }}$ moment does not exist, whereas in the $\operatorname{GARCH}(1,1)$ process, even if $\sum_{i=1}^{\infty} \delta_{i}=a_{1}\left(1-\beta_{1}\right)^{-1}>\left(a_{m}\right)^{-\frac{1}{m}}$, the $2 m$ th moment might exist because of the longer memory in GARCH process.

Higher moments indicate further interesting information about the nature of the GARCH process. Equations 7-8 estimate that if $3 a_{1}^{2}+2 a_{1} \beta_{1}+\beta_{1}^{2}<1$, the fourth-order moment (kurtosis) exists. Threfore since:

$$
E\left(\varepsilon_{t}^{2}\right)=a_{0}\left(1-a_{1}-\beta_{1}\right)^{-1}
$$

and

$$
\begin{aligned}
& E\left(\varepsilon_{\downarrow} t^{\uparrow} 4\right)=|| 3 \alpha_{\downarrow} 0^{\uparrow} 2\left(1+\alpha_{\downarrow} 1+\beta_{\downarrow} 1\right)\left[\left(1-\alpha_{\downarrow} 1-\beta_{\downarrow} 1\right)\right. \\
& \left(1-\beta_{\downarrow} 1^{\uparrow} 2-2 \alpha_{\downarrow} 1 \beta_{\downarrow} 1-3 \alpha_{\downarrow} 1^{\uparrow} 2\right]||^{\uparrow}(-1) .
\end{aligned}
$$


Equation 9 estimate the coefficient of kurtosis. Following:

$$
\begin{gathered}
K=\left(E\left(\varepsilon_{t}^{4}\right)-3 E\left(\varepsilon_{t}^{2}\right)^{2}\right) E\left(\varepsilon_{t}^{2}\right)^{-2}= \\
6 a_{1}^{2}\left(1-\beta_{1}^{2}-2 a_{1} \beta_{1}-3 a_{1}^{2}\right)^{-1},
\end{gathered}
$$

which is greater than zero by assumption, and hence greater than assumed under normal distribution. This means that a $\operatorname{GARCH}(1,1)$ process is leptokurtic, meaning that it has heavier tails than assumed under normal distribution, a property that the process shares with the $\operatorname{ARCH}(q)$ process. The property of being leptokurtic, although the probability distribution of stochastic variable $(\boldsymbol{\varepsilon})$ is normal, makes the ARCH and $\mathrm{GARCH}$ processes very convenient for modelling fat tailed observations, a characteristic that is usually displayed by asset returns. The lack of this property would mean that the modelling of heavy tailed behaviour of asset returns would require other, more computationally demanding distributions such as Student's t, GED or a mixture of normal distributions. In fact Nelson (1991) demonstrated that under suitable conditions, as time interval goes to zero, a $\operatorname{GARCH}(1,1)$ process approaches a continuous time process whose stationary unconditional distribution is Student's t.

In finance, the return of a security may depend on its volatility. To model such a phenomenon, Engle et al. (1987) introduced the ARCH in the mean (ARCH-M) model in which the conditional mean is a function of conditional variance of the process (Engle et al. 1987: 395):

$$
r_{t}=g\left(z_{t-1}, \sigma_{t}^{2}\right)+\sigma_{t} \varepsilon_{t},
$$

$Z_{t-1}$ is a vector of predetermined variables, $g$ is some function of $Z_{t-1}$ and $\sigma_{t}^{2}$ is generated by an ARCH(q) process. The most simple ARCH-M model has $g\left(z_{t-1}, \sigma_{t}^{2}\right)=\delta \sigma_{t}^{2}$. When $\sigma_{t}^{2}$ follows a GARCH process, Equation 10 will become a GARCH in the mean (GARCH-M) equation. A simple GARCH(1,1)-M model can be written as (Lucchetti and Rossi 2005: 310):

$$
\begin{gathered}
r_{t}=\mu+c \sigma_{t}^{2}+a_{t}, a_{t}=\sigma_{t} \varepsilon_{t}, \\
\sigma_{t}^{2}=\omega+a a_{t-1}^{2}+\beta \sigma_{t-1}^{2} .
\end{gathered}
$$

where $\mu$ and $c$ are constant. The parameter $\mathrm{c}$ is called the risk premium parameter. A positive $\mathrm{c}$ indicates that the return is positively related to its past volatility. The formulation of the GARCH-M model in Equation 11 implies that there are serial correlations in the return series $r_{t}$. These serial correlations are introduced by correlations in the volatility process $\left\{\sigma_{t}^{2}\right\}$. The existence of risk premium is, therefore, another reason that some historical stock returns have serial correlations. 
Another symmetric variation of the general form of GARCH model is the components GARCH model. When a GARCH model is estimated over a rolling data window, different long-term volatility levels will be estimated, corresponding to different estimates of the GARCH parameters. The components GARCH model extends this idea to allow variation of long-term volatility within the estimation period (Engle and Lee 1993a, b; Engle and Mezrich 1995). It is most useful in currency and commodity markets, where GARCH models are often close to being integrated and so convergent term structures that fit the market implied volatility term structure cannot be generated. The components model is an attempt to regain the convergence in GARCH term structures in currency markets, by allowing for a time-varying long-term volatility.

The GARCH $(1,1)$ conditional variance may be written in the form of Equation 12 . Following:

$$
\begin{aligned}
& \sigma_{t}^{2}=(1-a-\beta) \sigma^{2}+a \varepsilon_{t-1}^{2}+\beta \sigma_{t-1}^{2}= \\
& \sigma^{2}+a\left(\varepsilon_{t-1}^{2}-\sigma^{2}\right)+\beta\left(\sigma_{t-1}^{2}-\sigma^{2}\right)
\end{aligned}
$$

In components GARCH $\boldsymbol{\sigma}^{2}$ is replaced by a time-varying permanent component given by:

$$
q_{t}=\omega+p\left(q_{t-1}-\omega\right)+\zeta\left(\varepsilon_{t-1}^{2}-\sigma_{t-1}^{2}\right)
$$

Therefore the conditional variance equation in the components GARCH model is:

$$
\sigma_{t}^{2}=q_{t}+a\left(\varepsilon_{t-1}^{2}-q_{t-1}\right)+\beta\left(\sigma_{t-1}^{2}-q_{t-1}\right)
$$

Equations 13 and 14 together define the components GARCH model. If $p=1$ the permanent component to which long-term volatility forecasts mean-revert is just a random walk. While the components model has an attractive specification for currency markets, parameter estimation is, unfortunately not straightforward. Estimates may lack robustness and it seems difficult to recommend the use of the components model - except in the event that its specification has passed rigorous diagnostic tests.

Ding et al. (1993) developed the Power ARCH model, in which the power parameter $\beta_{1}$ of the standard deviation can be estimated rather than imposed, and the optional $\gamma$ parameters are added to capture asymmetry of up to order $r$ in Equation 15. Following:

$$
\sigma_{t}^{\beta_{1}}=\omega+\sum_{j=1}^{q} \beta j \sigma_{t-j}^{\beta_{1}}+\sum_{i=1}^{p} a_{i}\left(\left(\varepsilon_{t-i} \mid-\gamma_{i} \varepsilon_{t-i}\right)\right)^{\beta_{1}}
$$


where $\beta_{1}>0,\left|\gamma_{i}\right| \leq 1$ for $\mathrm{i}=1 \ldots \mathrm{r}, \gamma_{i}=0$ for all $\mathrm{i}>\mathrm{r}$, and $r \leq p$. The symmetric model sets $\gamma_{i}=0$ for all $i$. Note that if $\beta_{1}=2$ and $\gamma_{i}=0$ for all $i$, the PGARCH model is simply a standard GARCH specification. The asymmetric effects are present if $\gamma \neq 0$.

An important feature of financial returns known as "leverage effect", that was first documented by Black (1976) describes the tendency for changes in the financial returns, especially in the stock market, to be negatively correlated with changes in stock volatility. A part of this phenomenon can be explained by the fixed costs that companies incur, such as financial and operational leverage. Lowering of stock price reduces the value of company's equity relative to its debt, thus raising its debt to equity ratio, which raises the volatility of a stock making them riskier to hold. Black (1976) argues that the response of stock volatility to the direction of returns is too large to be explained by leverage alone. This conclusion is also supported by the work of Christie (1982) and Schwert (1989). Simply stated, if volatility is higher following a negative return than it is following a positive return, then the autocorrelation between yesterday's return and today's squared return will be large and negative.

It is interesting that empirical research using robust test statistics that are much more sophisticated than the simple Ljung-Box Q-test procedure, (see Hagerud 1997) has found that relatively few stocks show signs of asymmetric volatility clustering. Hagerud (1997) finds that only 12 out of his sample of 45 Nordic stocks exhibited a noticeable leverage effect. The volatility skew may still be very pronounced in these stocks, so where implied volatility smiles have noticeable skew effects, these may or may not be indicative of a leverage effect.

Literally, dozens of different variants of asymmetric GARCH models have been proposed and tested in a vast research literature. However, asymmetric GARCH models have a fairly limited practical use. It is a good thing to be able to include the possibility of asymmetry in the GARCH model so that any leverage effect will be captured, but one should do so with caution because the estimation of asymmetric GARCH models can be much more difficult than the estimation of symmetric GARCH models.

To overcome some weaknesses of the GARCH model in handling financial time series, Nelson (1991) proposed the exponential GARCH (EGARCH) model. The conditional variance equation in the E-GARCH model is defined in terms of a standard normal variate $Z_{t}$. In particular, to allow for asymmetric effects between positive and negative asset returns, he considers the weighted innovation (Nelson 1991: 351):

$$
g\left(z_{t}\right)=\lambda z_{t}+\vartheta\left(z_{t} \mid-E\left(z_{t} \mid\right)\right)
$$

where $\lambda$ and $\varphi$ are real constants. The parameter $\varphi$ allows for the asymmetry in the model. If $\varphi=0$ then a positive surprise $\left(\varepsilon_{t-j}>0\right)$ the same effect on volatility as a negative surprise of the same magnitude. If $-1<\varphi<0$ a positive surprise increases volatility less than a negative surprise. If $\varphi<-1$, a positive surprise actually reduces volatil- 
ity while a negative surprise increases volatility. A number of researchers have found evidence of asymmetry in stock price behaviour - negative surprises seem to increase volatility more than positive surprises of the same magnitude (Black 1976; Pagan and Schwert 1990; Engle and Ng 1993).

Both $z_{t}$ and $\left|z_{t}\right|-\mathrm{E}\left(\left|z_{t}\right|\right)$ are zero-mean IID sequences with continuous distributions. Therefore, $E\left[g\left(z_{\downarrow} t\right)\right]=0$. The asymmetry of $g\left(z_{t}\right)$ can be seen by rewriting Equation 16 into Equation 17. Following:

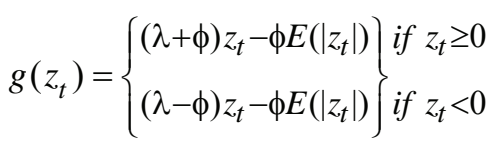

For the standard Gaussian random variable $\varepsilon_{t},\left(\left|z_{t}\right|\right)=\sqrt{2} / \pi$. For the standardized Student's t distribution $E\left(z_{t}\right)$ can be expressed as in Equation 18. Hence, $E\left(z_{t}\right)$ equals (McDonald 1996: 430):

$$
E\left(\left|z_{t}\right|\right)=\frac{1}{\sqrt{a} B\left(\frac{1}{2}, \frac{v}{2}\right)\left(1+\frac{2 z^{2}}{v \sigma^{2}}\right)^{\frac{v+1}{2}},}
$$

where B is a beta function ${ }^{2}$, and $\boldsymbol{v}$ is degrees of freedom.

$\operatorname{An} \operatorname{EGARCH}(p, q)$ model can be written as Equation 19 (Nelson 1991: 354):

$$
\ln \sigma_{t}^{2}=\omega+\frac{1+\beta_{1} B+\ldots+\beta_{p} B^{p}}{1-a_{1} B-\ldots-a_{q} B^{q}} g\left(z_{t-1}\right)
$$

where $\boldsymbol{\omega}, \boldsymbol{\alpha}$ and $\boldsymbol{\beta}$ are not restricted to be nonnegative, B is the back-shift (lag) operator such that $B g\left(z_{\downarrow} t\right)=g\left(z_{t-1}\right)$ and $1+\beta_{1} B+\ldots+\beta_{p} B^{p}$ and $1-a_{1} B-\ldots-a_{q} B^{q}$ are polynomials with absolute values of their zeros greater than one. Based on this representation, some properties of the EGARCH model can be obtained in a similar man-

2 Beta function, $B(p, q)$, is defined by (McDonald 1996: 455),

$$
B(p, q)=\int_{0}^{\infty} t^{p-1}(1-t)^{q-1} d t=\int_{0}^{\infty} \frac{t^{p-1}}{(1+t)^{p+q}} d t
$$

for positive $p$ and $q$. $\mathrm{B}(p, q)$ can also be expressed in terms of a gamma function:

$B(p, q)=\frac{\Gamma(p) \Gamma(q)}{\Gamma(p+q)}$. 
ner as those of the GARCH model. For instance, the unconditional mean of $\ln \left((\sigma)_{t}^{2}\right)$ is $\omega$. However, the model differs from the GARCH model in several ways. First, it uses logged conditional variance to relax the positiveness constraint of model coefficients. Second, the use of $g\left(z_{t}\right)$ enables the model to respond asymmetrically to positive and negative lagged values of $\boldsymbol{\varepsilon}_{t}$. Several studies have found that the exponential GARCH model fits financial data very well, often better than other GARCH models. Even without significant leverage effects, the logarithmic specification appears to have considerable advantages (Taylor 1994). Unfortunately, exponential GARCH is difficult to use for volatility forecasting because there is no analytic form for the volatility term structure.

GJR-GARCH model is similar to the EGARCH model in spirit but have better forecasting properties (Engle and Mezrich 1995). The GJR-GARCH model accounts for the asymmetry by allowing two different coefficients into the conditional volatility equation, and the GJR-GARCH model, by adding to volatility forecast in case of a negative return via an indicator function.

The GJR-GARCH put forward by Glosten et al. (1993) is given by Equation 20. Following:

$$
\sigma_{t}^{2}=\omega+\sum_{i=1}^{q}\left[a_{1}+\gamma_{i} l_{t}\right] \varepsilon_{t-i}^{2}+\sum_{j=1}^{p} \beta j \sigma_{t-j}^{2},
$$

$$
\begin{aligned}
& l_{t}=1 \quad \text { if } \quad \boldsymbol{\varepsilon}_{t-i}<0 \\
& l_{t}=0 \quad \text { if } \quad \boldsymbol{\varepsilon}_{t-i} \geq 0
\end{aligned}
$$

Positive surprises have an impact of $\alpha$ while negative surprises have an impact of $a+\gamma$.

\section{Empirical results and discussion}

Ljung-Box Q tests on mean adjusted returns and squared returns show that all analyzed stock indexes are characterized by significant autoregression and heteroskedasticity. The dynamics of the data generating processes are complex because changes in the efficiency of the market alter the long-run level and persistence of volatility. Furthermore, there is ample of empirical evidence on a positive relationship between trading volume and volatility. Supposing that some predictability (significant AR term) is present in the series, increasing efficiency tends to lower the level and persistence of volatility, but larger volume might push its level up. Volatility can be raised due to other reasons too, for example when news in the return series arrives more often and is of a larger magnitude than usual (shift in the volatility of error term). The increasing integration of the local stock markets into the global capital market may only further amplify this effect. 
The estimation procedure consists of two parts. Since the final goal is to obtain identically and independently distributed (IID) innovation we first clean the conditional mean structure of the return series from the autoregression by using an $\operatorname{ARMA}(p, q)$ model. The order of $\operatorname{ARMA}(\mathrm{p}, \mathrm{q})$ for each index is determined according to smallest value of Bayesian information criterion (BIC). Since the conditional mean equation for all of the Baltic indexes is complex in case of we RIGSE index even had to use $\operatorname{ARMA}(3,3)$ model to successfully get rid of autocorrelation. In the next step, we estimate six different GARCH models in order to capture conditional variance and volatility clustering and get the insight into the true nature of volatility in the Baltic stock markets. Table 2 reports the parameter estimates of all tested GARCH volatility models that were described in the previous section. For TALSE and BALTIC benchmark indexes, the sum of ARCH and GARCH coefficients is very close to one, indicating that the series is close to being integrated. Based on GARCH parameters TALSE index has the highest volatility persistence $(0.896)$ and RIGSE index has the lowest volatility persistence (0.664), meaning that the shocks - "old news" in this time series fade unusually quickly. The mean values of GARCH volatility are significant for all of the indexes. The highest value is recorded for the RIGSE index (0.1), while the lowest value is recorded for BALTIC benchmark index (0.009). This means that, over the analysed period, RIGSE had the highest volatility while, as expected, due to the effect of diversification BALTIC benchmark index was the least volatile index.

A very interesting finding is the result from GARCH-M estimation which shows that the coefficients of the conditional variance in the mean equation, denoted as $\boldsymbol{\beta}_{2}$, are negative but insignificant. This suggests that higher conditional volatility - market risk is not significantly related to negative returns.

Asymmetric EGARCH model parameters show the existence of the leverage effect in returns of all analysed indexes during the sample period. Surprisingly, we find the existence of a significant negative leverage $(\boldsymbol{\gamma})$ parameter for VILSE and RIGSE index, as oppose to TALSE and BALTIC benchmark where this parameter is significantly positive. The evidence is that much strong since GJR-GARCH model tells the same story. In case of VILSE and RIGSE index negative leverage parameter in EGARCH model (i.e. positive leverage parameter in GJR-GARCH model) means that as expected under the "leverage effect" paradigm "bad news" - negative returns increases volatility. As opposed to this in case of TALSE and BALTIC benchmark index the relation is reversed in that "good news" - positive returns increases volatility.

The results of the estimation of $\mathrm{CGARCH}(1,1)$ model show that the long-run component is significant and positive for all indexes except VILSE index. The results of the estimation of APARCH(1,1) model confirm that the asymmetric effects are present in TALSE and VILSE index (the asymmetric parameter is of the same sign as indicated by GJR-GARCH model). 


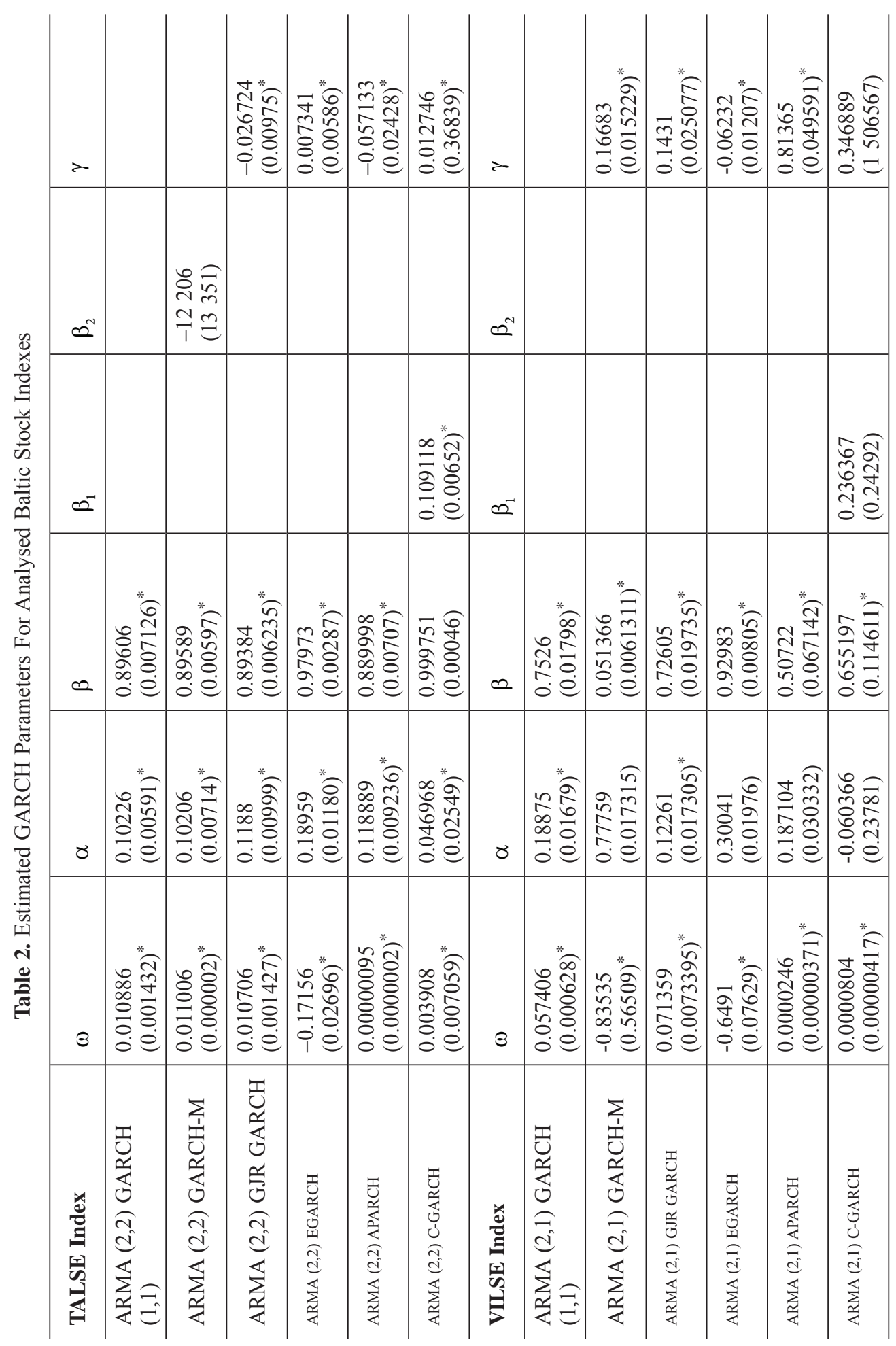




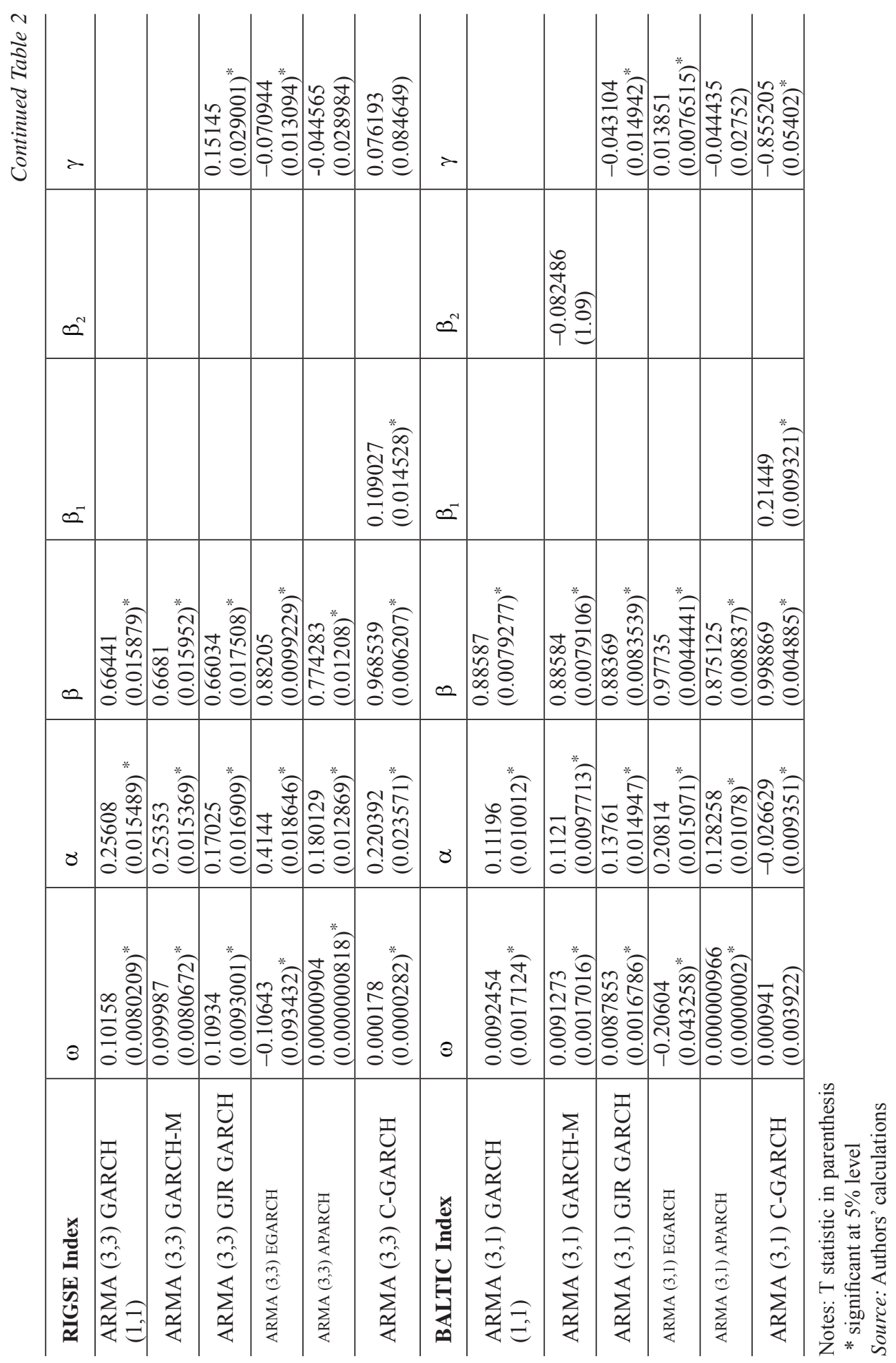




\section{Conclusion}

This paper addresses the issue of conditional volatility modelling by using symmetric and asymmetric GARCH models on daily returns from Baltic stock markets. We empirically investigate stock market volatility using daily data from three Baltic stock indices and their joint benchmark index, namely Estonia (TALSE index), Latvia (RIGSE index), Lithuania (VILSE index), and BALTIC benchmark index. We find strong evidence that daily volatility from Baltic stock markets can be explained by GARCH-family models. For TALSE and BALTIC benchmark indexes, the sum of ARCH and GARCH coefficients is very close to one, indicating that the series is close to being integrated. During the analysed period, RIGSE had the highest volatility while, as expected, due to the effect of diversification BALTIC benchmark index was the least volatile index. A very interesting finding is the result from GARCH-M estimation which shows that the coefficients of the conditional variance in the mean equation are negative but insignificant, suggesting that higher conditional volatility - market risk is not related to negative returns. Asymmetric EGARCH model parameters show the existence of the leverage effect in returns of all analysed indexes during the sample period. We find the existence of a significant negative leverage parameter for VILSE and RIGSE index, as opposed to TALSE and BALTIC benchmark where this parameter is significantly positive. The evidence is that much strong since GJR-GARCH and APARCH model tells the same story. In case of VILSE and RIGSE index negative leverage parameter in EGARCH model (i.e. positive leverage parameter in GJR-GARCH model) means that as expected under the "leverage effect" paradigm "bad news" - negative returns increases volatility. As opposed to this in case of TALSE and BALTIC benchmark index the relation is reversed in that "good news" - positive returns increases volatility. These findings are of interest to risk managers and investors investing in Baltic stock markets.

\section{References}

Adekola, A.; Korsakienė, R.; Tvaronavičienè, M. 2008. Approach to innovative activities by Lithuanian companies in the current conditions of development, Technological and Economic Development of Economy 14(4): 595-611. doi:10.3846/1392-8619.2008.14.595-611

Akgiray, V. 1989. Conditional Heteroscedasticity in Time Series of Stock Return: Evidence and Forecast, Journal of Business 62(1): 55-80. doi:10.1086/296451

Alexander, C. 2000. Risk Management and Analysis, Measuring and Modelling Financial Risk. New York: John Wiley \& Sons. 304 p. ISBN-10: 0471979570.

Alexander, C. 2001. Market Models: A Guide to Financial Data Analysis. New York: John Wiley \& Sons. 514 p. ISBN13: 9780471899754.

Aslanidis, N.; Osborn, D. R.; Sensier, M. 2009. Co-Movements between US and UK Stock Prices: The Role of Time-Varying Conditional Correlations, International Journal of Finance and Economics [online], [accessed 6 May 2010]. Available from Internet: < http://www3.interscience.wiley.com/ journal/122528310/abstract>.

Black, F. 1976. Studies of stock price volatility changes, in Proceedings of the 1976 Meeting of the Business and Economics Statistics Section, Washington, DC: American Statistical Association, $177-181$. 
Blattberg, C. R.; Gonedes, J. N. 1974. A Comparison of the Stable and Student Distribution of Statistical Models for Stock Prices, Journal of Business 47(2): 244-280. doi:10.1086/295634

Bollerslev, T. 1986. Generalized Autoregressive Conditional Heteroscedasticity, Journal of Econometrics 31(3): 307-327. doi:10.1016/0304-4076(86)90063-1

Christiansen, C. 2010. Decomposing European Bond and Equity Volatility, International Journal of Finance and Economics 15(2): 105-122. doi:10.1002/ijfe.385

Christie, A. A. 1982. The Stochastic Behavior of Common Stock Variance: Value, Leverage and Interest Rate Effects, Journal of Financial Economics 10(4): 407-432. doi:10.1016/0304-405X(82)90018-6

Clark, K. P. 1973. A Subordinated Stochastic Process Model with Finite Variance for Speculative Prices, Econometrica 41: 135-156. doi:10.2307/1913889

Teresiene, D. 2009. Lithuanian Stock Market Analysis Using a Set of Garch Models, Journal of Business Economics and Management 10(4): 349-360. doi:10.3846/1611-1699.2009.10.349-360

Ding, Z.; Granger, C. W. J.; Engle, F. R. 1993. A Long Memory Property of Stock Markets Returns and A New Model, Journal of Empirical Finance 1(1): 83-106. doi:10.1016/0927-5398(93)90006-D

Enders, W. 2004. Applied Econometric Time Series. $2^{\text {nd }}$ edition, New York, John Wiley \& Sons, 480 p. ISBN: 978-0-471-23065-6.

Engle, F. R. 1982. Autoregressive Conditional Heteroscedasticity with Estimates of the Variance of United Kingdom Inflation, Econometrica 50(4): 987-1008. doi:10.2307/1912773

Engle, F. R.; Lilien, M. D.; Robins, P. R. 1987. Estimating Time-Varying Risk Premia in the Term Structure: The ARCH-M Model, Econometrica 55(2): 391-407. doi:10.2307/1913242

Engle, F. R.; Lee, G. J. G. 1993a. Long Run Volatility Forecasting for Individual Stocks in a One Factor Model, Manuscript, University of California, San Diego. 93 p.

Engle, F. R.; Lee, G. J. G. 1993b. A Permanent and Transitory Component Model of Stock Return Volatility, Discussion paper 92-44R, University of California, San Diego. 130 p.

Engle, F. R.; Ng, K. V. 1993. Measuring and Testing the Impact of News on Volatility, Journal of Finance 48(5): 1749-1778. doi:10.2307/2329066

Engle, F. R.; Mezrich, J. 1995. Grappling with GARCH, Risk 8(9): 112-117.

Fama, F. E. 1965. The Behavior of Stock Market Prices, Journal of Business 38: 34-105. doi:10.1086/294743

Glosten, R. L.; Jagannathan, R.; Runkle, E. D. 1993. On the Relation between the Expected Value and the Volatility of the Nominal Excess Return on Stocks. Federal Reserve Bank of Minneapolis, Research Department Staff Report 157: 1-36.

Gurgul, H.; Majdosz, P.; Mestel, R. 2006. Implications of Dividend Announcements for Stock Prices and Trading Volume of DAX Companies, Czech Journal of Economics and Finance 56(1-2): 58-68.

Hagerud, E. G. 1997. Specification Test for Asymmetric GARCH, Working Paper Series in Economics and Finance 163: 1-32.

Kearney, C.; Daly, K. 1998. The Causes of Stock Market Volatility in Australia, Applied Financial Economics 8(6): 597-605. doi:10.1080/096031098332637

Kim, D.; Kon, S. I. 1994. Alternative Models for Conditional Heteroscedasticity of Stock Returns, Journal of Business 67(4): 563-598. doi:10.1086/296647

Lucchetti, R.; Rossi, E. 2005. Artificial Regression Testing in the GARCH-in-Mean Model, Econometrics Journal 8(3): 306-322. doi:10.1111/j.1368-423X.2005.00166.x

Mandelbrot, B. 1963. The Variation of Certain Speculative Prices, Journal of Business 36: 394-419. doi:10.1086/294632

Mcmillan, D. G.; Speight, A. E. H. 2006. Volatility Dynamics and Heterogeneous Markets, International Journal of Finance and Economics 11(2): 115-121. doi:10.1002/ijfe.281 
McDonald, B. J. 1996. Probability Distributions for Financial Models, in G.S. Maddala and C.R. Rao. Handbook of Statistics, Elsevier Science 14: 427-461.

Melnikas, B. 2008. Integral Spaces in the European Union: Possible Trends of the Social, Economic and Technological Integration in the Baltic Region, Journal of Business Economics and Management 9(1): 65-77. doi:10.3846/1611-1699.2008.9.65-77

Nelson, B. D. 1991. Conditional Heteroskedasticity in Asset Returns: A New Approach, Econometrica 59(2): 347-370. doi:10.2307/2938260

Pagan, R. A.; Schwert, G. W. 1990. Alternative Models for Conditional Stock Volatility, Journal of Econometrics 45(1-2): 267-290. doi:10.1016/0304-4076(90)90101-X

Pilinkus, D. 2010. Macroeconomic Indicators and Their Impact on Stock Market Performance in the Short and Long Run: The Case of the Baltic States, Technological and Economic Development of Economy 16(2): 291-304. doi:10.3846/tede.2010.19

Po ta, V. 2008. Estimating the Dynamics of Weak Efficiency on the Prague Stock Exchange Using the Kalman Filter, Czech Journal of Economics and Finance 58(5-6): 248-260.

Schwert, G. W. 1989. Why Does Stock Market Volatility Change Over Time? Journal of Finance 44(5): 1115-1153. doi:10.2307/2328636

Sentana, E.; Wadhwani, S. 1992. Feedback Traders and Stock Return Autocorrelations: Evidence From a Century of Daily Data, Economic Journal 102: 415-425. doi:10.2307/2234525

Tay, N. S. P.; Zhu, Z. 2000. Correlations in Returns and Volatilities in Pacific-Rim Stock Markets, Open Economies Review 11(1): 27-47. doi:10.1023/A:1008349012883

Tvaronavičienè, M.; Grybaitè, V.; Tvaronavičienè, A. 2009. If Institutional Performance Matters: Development Comparisons of Lithuania, Latvia and Estonia, Journal of Business Economics and Management 10(3): 271-278. doi:10.3846/1611-1699.2009.10.271-278

Taylor, S. J. 1994. Modelling Stochastic Volatility: A Review and Comparative Study, Mathematical Finance 4(2): 183-204. doi:10.1111/j.1467-9965.1994.tb00057.x

\section{BALTIJOS VERTYBINIŲ POPIERIŲ RINKŲ NEPASTOVUMO MODELIAVIMAS}

\section{B. Aktan, R. Korsakienė, R. Smaliukienė}

\section{Santrauka}

Straipsnyje analizuojamas sąlyginis Baltijos vertybiniu popierių rinkų (Estijos, Latvijos ir Lietuvos) nepastovumas, taikant eilę GARCH kintamumo modelių. Pažymėtina, kad tinkamai prognozuojant nepastovumą, galima geriau suvokti ir valdyti finansinių rinkų riziką. Straipsnyje remiamasi keturiu Baltijos šalių kasdienėmis akcijų indeksu grąžomis; Estijos (TALSE indeksu), Latvijos (RIGSE indeksu), Lietuvos (VILSE indeksu) ir sintetiniu palyginamuoju BALTIC indeksu. Pritaikius eilę GARCH kintamumo modelių, galima teigti, kad didejjanti rizika Baltijos šalių rinkose nebūtinai itakos vertybiniu popieriu gražzos augimą. Tyrimo metu gauti rezultatai rekomenduojami finansų specialistams ir investuotojams.

Reikšminiai žodžiai: Baltijos vertybinių popierių rinkos, sąlyginis nepastovumas, GARCH modeliai, finansinè rizika, grąža.

Bora AKTAN. Assistant Professor of Finance and Deputy Chair of International Trade and Finance Department at Yasar University, Faculty of Economics and Administrative Sciences. Prior to joining the Yasar University, Dr Aktan worked as both Corporate Strategy and Business Development Director in international firms largely active in Mexico, England and Turkey. Dr Aktan's current research activity focuses on global investing, financial characteristics and performance of firms in emerging countries, 
emerging capital markets, energy price volatility, and risk-return trade-off in asset prices, corporate governance and business ethics. He has published in different refereed journals such as Journal of Business Economics and Management, International Research Journal of Finance and Economics, Investment Management and Financial Innovations, Journal of Property Investment and Finance. He is member of some professional bodies such as The International Institute of Forecasters (IIF), The American Finance Association (AFA), The Society for Financial Econometrics (SoFIE) and the Financial Management Association (FMA). Dr Aktan is also on the editorial boards of several international scholarly journals such as Qualitative Research in Financial Markets, Journal of Applied Sciences, Asian Journal of Mathematics and Statistics, Journal of Artificial Intelligence, Academy of Banking Studies Journal, among others. In addition, he serves as a board member of Economics and Financial Affairs Committee for the Aegean Region Chamber of Industry.

Renata KORSAKIENE். Associate Professor, Dr, Department of Enterprise Economics and Management, Vilnius Gediminas Technical University. Research interests: international economics, strategic management, innovation management, change management.

Rasa SMALIUKIENE். Associate Professor, Dr, Department of International Economics and Management, Vilnius Gediminas Technical University. Research interests: international economics, marketing, strategic management, leadership. 